\title{
Analisis Pengaruh Perubahan Beban Terhadap Karakteristik Generator Sinkron
}

\author{
Annisa $^{1}$, Winarso ${ }^{2}$, Wakhyu Dwiono ${ }^{3}$ \\ Program Studi S1 Teknik Elektro, Universitas Muhammadiyah Purwokerto \\ Fakultas Teknik dan Sains, Universitas Muhammadiyah Purwokerto
}

\section{Informasi Makalah}

Dikirim, 3 Mei 2019

Direvisi, 1 Juli 2019

Diterima,

\section{Kata Kunci:}

efisiensi generator generator sinkron perubahan beban

\section{Keyword:}

generator eficiency

load change

synchronous generator.

\begin{abstract}
INTISARI
Generator sinkron adalah mesin sinkron pengubah energi mekanik menjadi energi listrik yang memiliki frekuensi putar rotor sama dengan frekuensi tegangan yang dibangkitkan. Hampir semua energi listrik di Indonesia dibangkitkan dengan menggunakan generator sinkron, sehingga keberadaannya sangat berpengaruh terhadap kontinuitas pelayanan. Salah satu faktor yang mempengaruhi karakteristiknya adalah perubahan beban generator. Pada penelitian ini dilakukan sebuah perhitungan dan analisis pengaruh perubahan beban terhadap karakteristik generator sinkron unit \& 2 di PT Sumber Segara Primadaya. Berdasarkan hasil dari data di lapangan diperoleh efisiensi generator unit $1 \& 2$ berada pada rentang $97,12 \%$ sampai dengan $98,73 \%$, angka ini cukup baik mengingat rugi yang dihasilkan maksimal hanya sebesar $2,88 \%$.
\end{abstract}

\begin{abstract}
Synchronous generator is a synchronous machine which converting mechanical energy into electrical energy which has a turn of rotor frequency same with a raise voltage frequency. Almost all of the electrical power in Indonesia are raised up by synchronous generators, so its existence is very influential towards service continuity. One of the factors that effects its characteristics is generator load change. In this research, there were a calculation and an analysis of the load change effect towards synchronous generators unit $1 \& 2$ characteristics in PT Sumber Segara Primadaya. According to the field datasets, there was a generators unit $1 \& 2$ efficiency which on the range $97,12 \%$ to $98,73 \%$, these numbers are good enough remembering the maximum losses is only $2,88 \%$.
\end{abstract}

\section{Korespondensi Penulis:}

Annisa

Program Studi S1 Teknik Elektro

Universitas Muhammadiyah Purwokerto

Jl. Raya Dukuh Waluh Purwokerto, 53182

Email: sasa.annisa.0404@gmail.com

\section{PENDAHULUAN}

Saat ini tidak bisa dipungkiri lagi bahwa hampir seluruh umat manusia di dunia memiliki ketergantungan terhadap energi listrik, sehingga bisa dibayangkan bila tiba-tiba seluruh catu daya listrik di bumi terhenti, maka akan banyak terjadi kekacauan dalam berbagai aspek. Dari sudut pandang politik, penggunaan energi tergantung pada kebijakan negara penyuplai, hal ini dapat mempengaruhi proses ekonomi dan politik di negara tersebut. Sistem otonomi penyediaan energi dapat membawa kontribusi signifikan untuk meningkatkan kekuatan negara (Genadijs Zaleskis, 2013). 
Energi listrik adalah bentuk energi yang paling efektif, paling mudah dan paling efisien dalam cara penggunaannya. Energi listrik dapat diproduksi dengan berbagai cara dari sumber awal yang berbeda-beda, yaitu air, minyak, gas, batubara, angin, cahaya matahari, panas bumi, dan lain-lain (Tumiran, 2002). Generator sinkron merupakan alat listrik yang berfungsi mengkonversikan energi mekanis berupa putaran menjadi energi listrik. Energi mekanis berupa putaran tersebut dihasilkan oleh penggerak mula (prime mover) yang dapat berupa turbin, mesin diesel, baling- baling dan lain-lain. Sedangkan energi listrik dikeluarkan oleh kumparan jangkar generator. Generator yang biasa digunakan dalam sistem pembangkitan adalah jenis generator sinkron atau serempak dimana tegangan dan frekuensi yang dihasilkan sesuai dengan kecepatan putarnya, sehingga diperlukan putaran yang konstan untuk menghasilkan tegangan dan frekuensi yang juga konstan. Untuk mendapatkan tegangan dan frekuensi yang konstan pada terminal generator maka arus jangkar dan sudut daya harus tetap pula. Besarnya perubahan beban generator perlu diketahui dan disesuaikan dengan kemampuan generator sehingga kestabilan kinerja generator dapat tercapai.

Dalam pembangkitan GGL induksi pada generator sinkron dibutuhkan arus penguatan (eksitasi) untuk mengatur kuat medan magnet pada kutub-kutub generator yang terletak pada rotor. "Sistem penguatan medan magnet (excitation) berfungsi mengendalikan output berupa tegangan, arus dan daya reaktif dari generator agar tetap stabil pada beban sistem yang fluktuatif dengan cara mengatur besaran-besaran input untuk mencapai titik keseimbangan baru" (Pandita M, 2015).

Menurut definisi IEEE: Stabilitas sistem tenaga adalah kemampuan sistem tenaga listrik untuk memberikan kondisi operasi mula, untuk kembali pada keadaan seimbang setelah mengalami gangguan fisik (Fetissi Selwa, 2014). [4] Berdasarkan permasalahan diatas maka kinerja generator penting untuk dikaji, dengan menganalisis pengaruh perubahan beban pada generator sinkron

\section{METODE PENELITIAN}

\subsection{Mengumpulkan Data}

Data-data yang diperlukan berupa:

a. Data teknis generator sinkron 3 fasa.

b. Data pengukuran daya aktif, daya reaktif, arus beban, tegangan output, dan arus eksitasi

\subsection{Mengolah Data}

Pengolahan data yang akan akan dilakukan meliputi:

a. Membuat simulasi generator sinkron 3 fasa dengan Simulink Matlab.

b. Melakukan pengujian simulasi generator.

c. Menghitung rugi total pada generator sinkron.

d. Membuat kurva penaikan dan penurunan beban harian generator.

e. Membuat kurva hubungan antara beban yang dilayani terhadap tegangan output (Vout).

f. Membuat kurva hubungan antara beban yang dilayani terhadap arus beban (Ia).

g. Membuat kurva hubungan antara beban yang dilayani terhadap arus medan (If).

h. Membuat kurva hubungan antara beban yang dilayani terhadap efisiensi generator.

\subsection{Analisis}

Hasil pengolahan data akan dianalisis seberapa besar pengaruh perubahan beban terhadap karakteristik generator sinkron 3 fasa terhadap tegangan output, arus beban, arus eksitasi, dan efisiensinya. Serta analisis pengujian simulasi generator denga Simulink Matlab.

\subsection{Rekomendasi}

Selanjutnya hasil analisis data yang sudah di lakukan akan menjadi dasar dalam penetuan rekomendasi untuk menjaga kestabilan kinerja generator.

Halaman Web JRRE : http://jurnalnasional.ump.ac.id/index.php/JRRE 


\section{HASIL DAN PEMBAHASAN}

\subsection{Technical Data}

Type: QFSN-300-2-20B

Rated Output: 300 MW (353 MVA) Maximum continues Output:330 MW (388 MVA)

Rated voltage: $20 \mathrm{kV}$ Rated current: 10,189 kA Rated power factor: 0,85

Rated frequency: $50 \mathrm{~Hz}$ Rated speed: $3000 \mathrm{r} / \mathrm{min}$ Number of phases: 3

Stator winding connecting: Y Number of terminal: 6

Insulation class: $\mathrm{F}$ (temp. limited in B class)

Cooling mode: $\mathrm{H} 2$

DC resistance of stator winding (per phase): $0,001658 \Omega$ (at 15o C)

Total loss: $3370,5 \mathrm{KW}$

\subsection{Perhitungan Rugi Total dan Efisiensi Generator}

Untuk menghitung efisiensi generator dapat dihitung menggunakan persamaan:

$$
\eta=\frac{P \text { out }}{P \text { out }+P \text { Loss Total }} \times 100 \%
$$

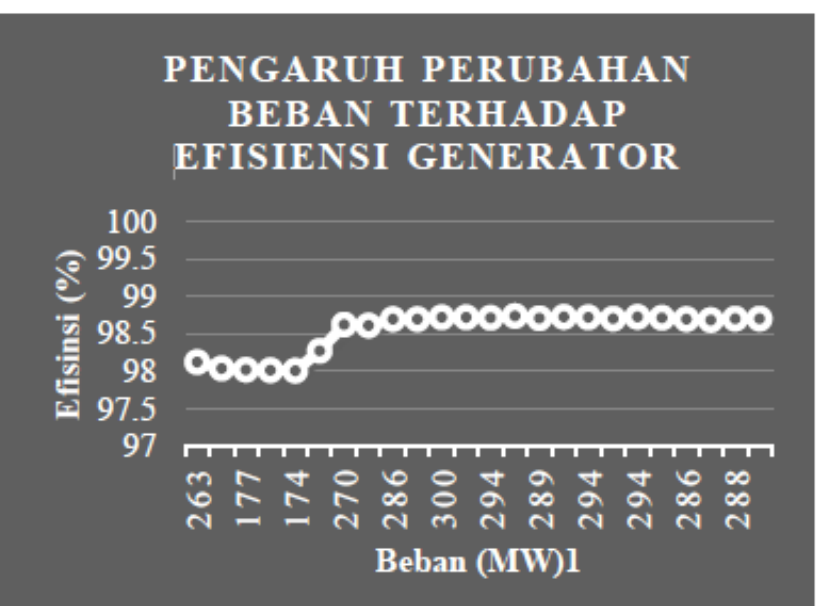

Gambar 3.1 Grafik Perubahan Beban terhadap Efisiensi Generator Unit 1

PT Sumber Segara Primadaya pada Tanggal 1 Februari 2018 


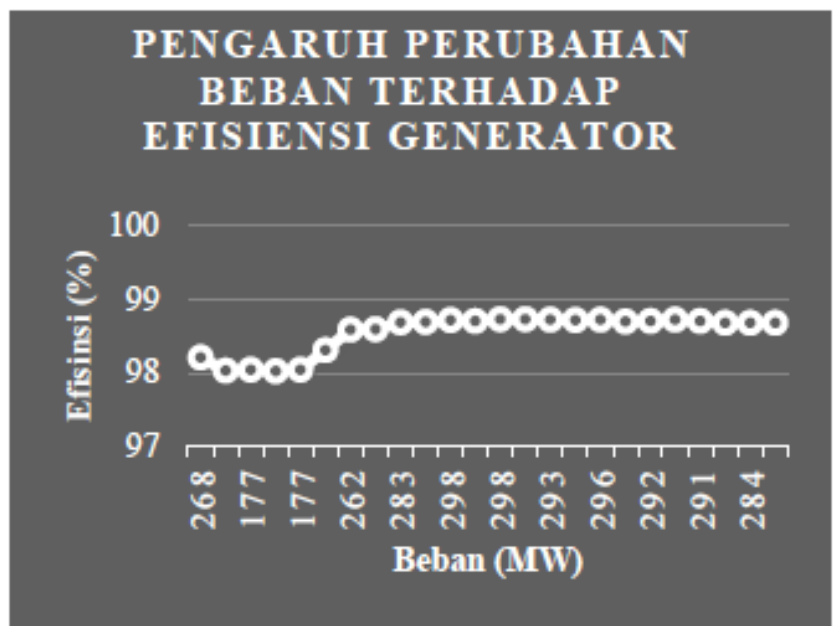

Gambar 3.2 Grafik Perubahan Beban terhadap Efisiensi Generator Unit 2

PT Sumber Segara Primadaya padaTanggal 1 Februari 2018

Ketika beban naik maka arus eksitasi akan naik. Ketika arus eksitasi naik maka cos phi yang dihasilkan akan turun. Hal itu karena ketika beban naik dan arus eksitasi naik maka daya reaktif yang dihasilkan akan naik pula. Ketika daya reaktif meningkat, maka sudut daya yang dihasilkan semakin besar. Kenaikan perbedaan sudut daya akan menyebabkan cos phi yang dihasilkan lebih rendah

Hal ini berkaitan langsung terhadap efisiensi generator. Cos phi yang rendah mempengaruhi rugi-rugi yang terdapat pada generator. Semakin rendah cos phi yang dihasilkan, maka semakin besar rugi-rugi yang ditimbulkan, dengan demikian efisiensi generator pun semakin rendah. Menurut data yang telah diperoleh, efisiensi generator unit $1 \& 2$ berada pada rentang 97,12\% sampai dengan 98,73\%. Angka ini cukup baik mengingat rugi yang dihasilkan maksimal hanya sebesar 2,88\%

\subsection{Proses Penaikan dan Penurunan Beban Generator}

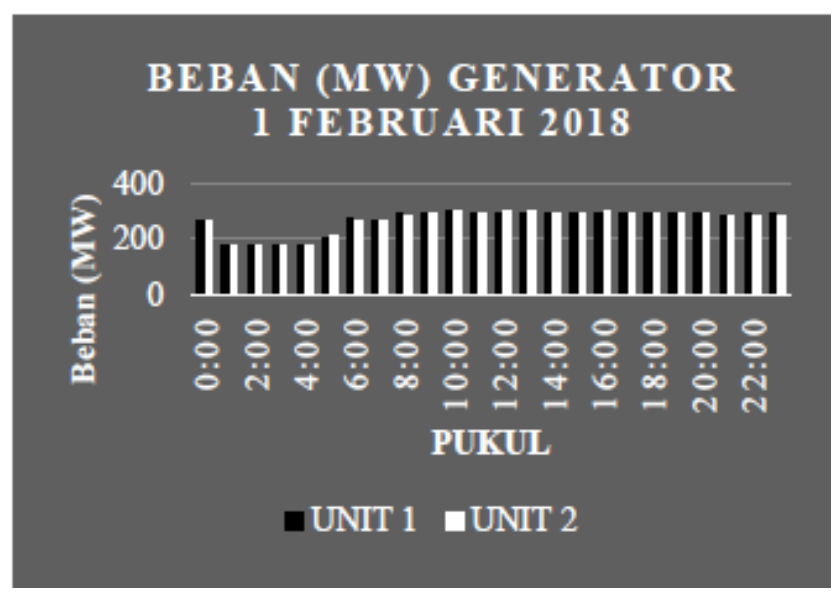

Gambar 3.3 Grafik Perubahan Beban Generator PT Sumber Segara Primadaya pada Tanggal 1 Februari 2018 


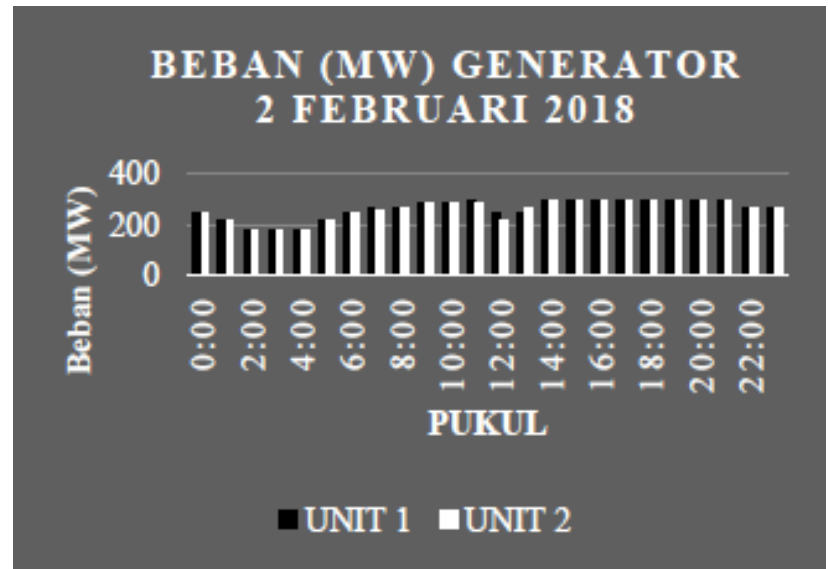

Gambar 3.4 Grafik Perubahan Beban Generator PT Sumber Segara Primadaya pada Tanggal 2 Februari 2018

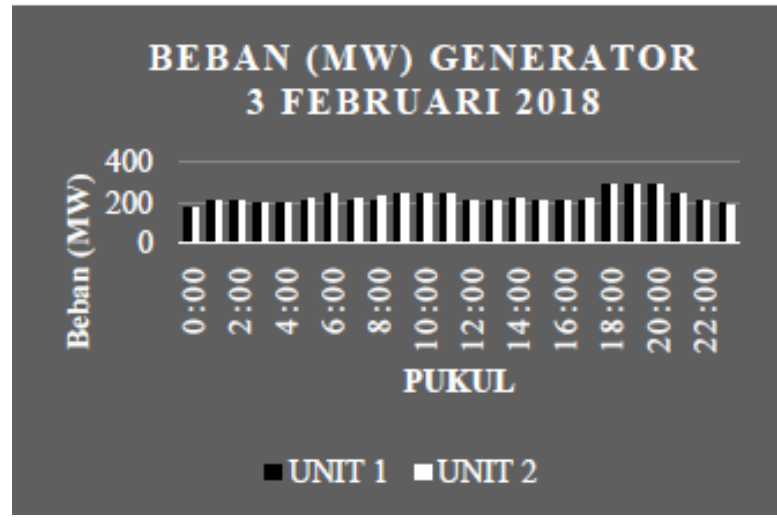

Gambar 3.5 Grafik Perubahan Beban Generator PT Sumber Segara Primadaya pada Tanggal 3 Februari 2018 


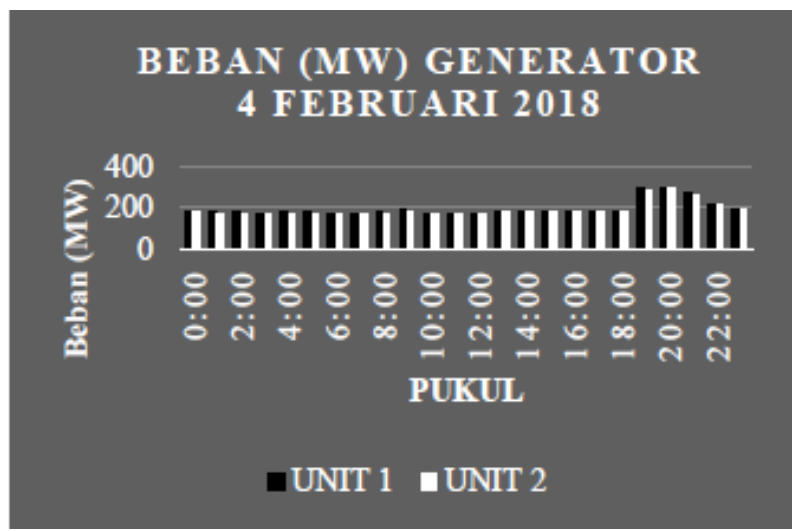

Gambar 3.6 Grafik Perubahan Beban Generator PT Sumber Segara Primadaya pada Tanggal 4 Februari 2018

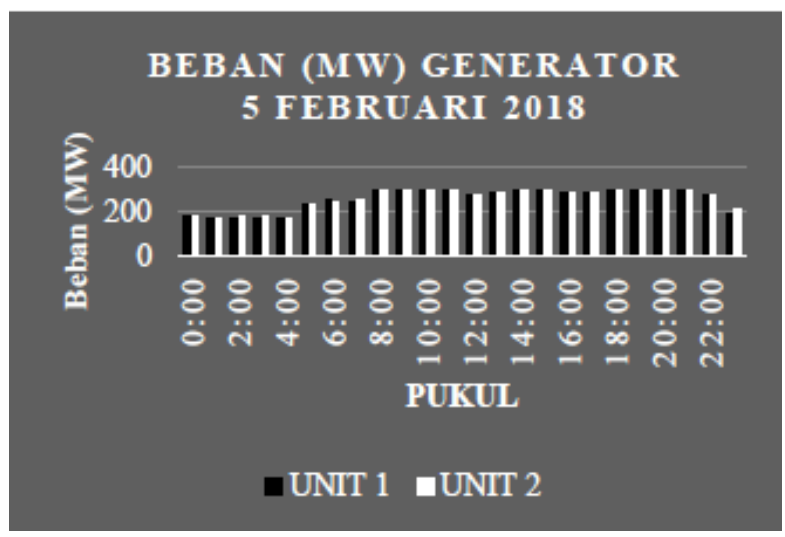

Gambar 3.7 Grafik Perubahan Beban Generator PT Sumber Segara Primadaya pada Tanggal 5 Februari 2018

Beban generator unit $1 \&$ unit 2 bersifat sangat fluktuatif. Proses penaikan dan penurunan beban pada generator ini disebabkan karena permintaan energi listrik yang diatur oleh PLN. Umumnya beban tinggi terjadi pada pukul 19.00 - 21.00 WIB dimana pada rentang waktu ini masyarakat secara bersamaan menghidupkan peralatan listrik. Di luar jam tersebut umumnya pembangkit tidak bekerja penuh dari kapasitas yang ada. Sistem kelistrikan PT Sumber Segara Primadaya terhubung dengan sistem interkoneksi Jawa bagian selatan sehingga listrik yang disalurkan terhubung ke beberapa daerah dan beberapa GI. Apabila suatu daerah kekurangan pasokan daya listrik maka pembangkit lain yang mempunyai kepasitas lebih akan menyalurkan ke daerah tersebut. Sistem interkoneksi diatur oleh PLN dengan melihat pemakaian beban fluktuatif masyarakat di setiap daerah 
3.4. Pengaruh Perubahan Beban terhadap Tegangan Output Generator

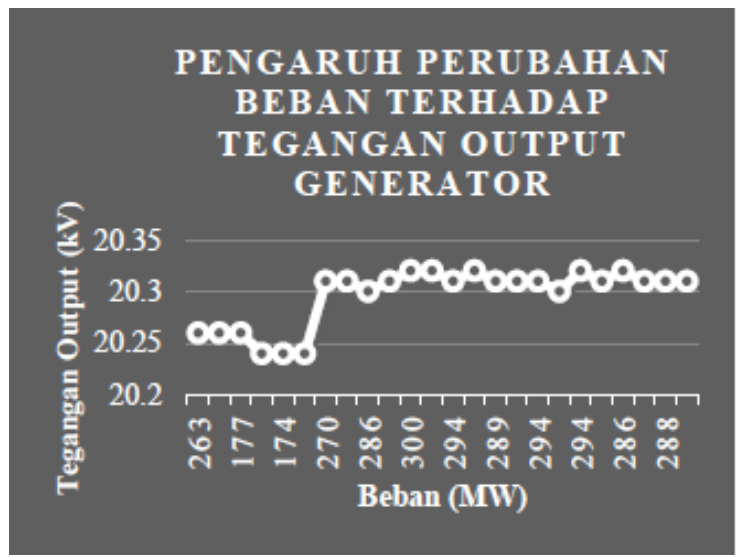

Gambar 3.8 Grafik Perubahan Beban terhadap Tegangan Output Generator Unit 1 PT Sumber Segara Primadaya

Stabilitas tegangan output generator baik. Sistem pengoperasian AVR (Automatic Voltage Regulator) berfungsi untuk menjaga agar tegangan generator tetap konstan, dengan kata lain generator akan tetap mengeluarkan tegangan yang selalu stabil tidak terpengaruh pada perubahan beban yang selalu berubah- ubah. Prinsip kerja AVR adalah mengatur arus penguatan pada exciter. Apabila tegangan output generator di bawah tegangan nominal teganga generator, maka AVR akan memperbesar arus eksitasi pada exciter. Dan juga sebaliknya apabila tegangan output generator melebihi tegangan nominal generator maka AVR akan mengurangi arus penguatan pada exciter. Dengan demikian apabila terjadi perubahan tegangan output generator akan dapat distabilkan oleh AVR secara otomatis

\subsection{Pengaruh Perubahan Beban teradap Arus Beban}

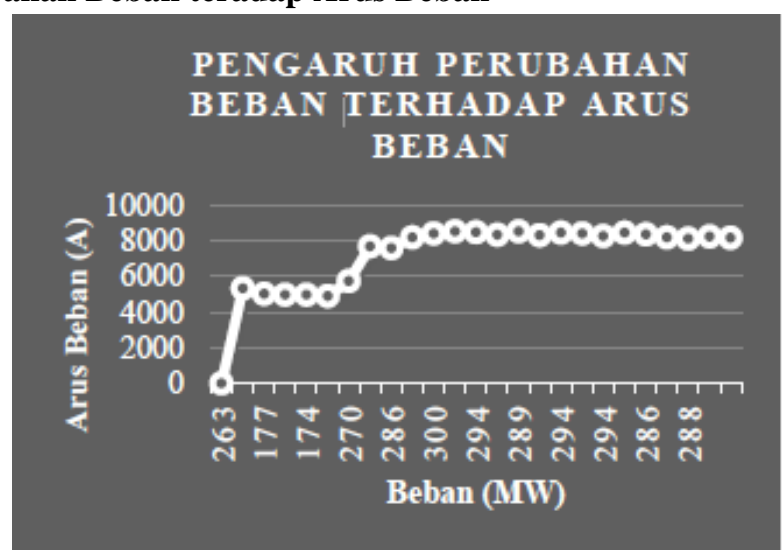

Gambar 3.9 Grafik Perubahan Beban terhadap Arus Beban

Generator Unit 1 PT Sumber Segara Primadaya 
Perubahan beban berbanding lurus mempengaruhi arus beban generator. Sejalan dengan Hukum Ohm, maka ketika terjadi perubahan beban, arus bebannya akan meningkat karena resistansi penghantar yang tidak berubah serta tegangannya tetap.

\subsection{Pengaruh Perubahan Beban terhadap Arus Eksitasi}

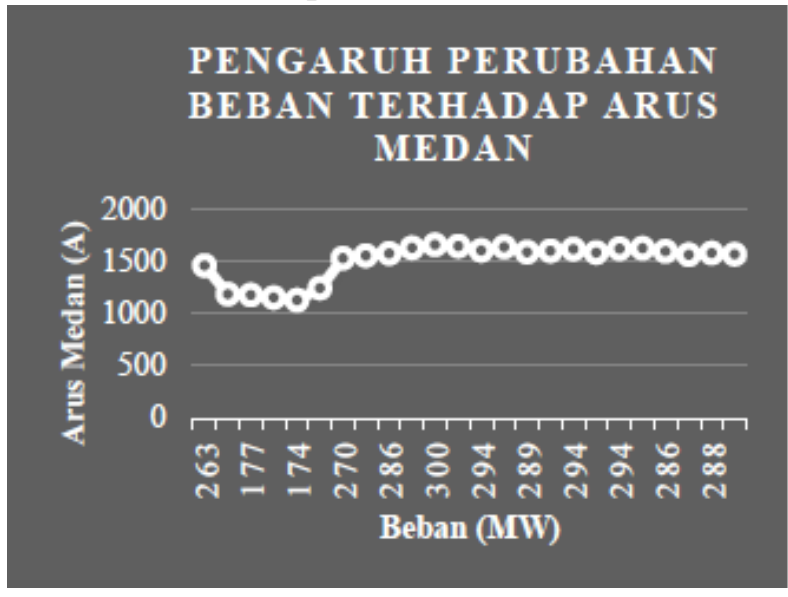

Gambar 3.10 Grafik Perubahan Beban terhadap Arus Medan Generator Unit 1 PT Sumber Segara Primadaya

Dari data yang diambil dari hasil report generator unit $1 \&$ unit 2 pada tanggal 1 Februari 2018 menunjukan bahwa perubahan beban akan mempengaruhi arus eksitasi. Ketika beban meningkat, maka pengaturan uap masuk juga ditingkatkan dengan mengubah set point governor dimana putaran dan tegangan dibuat tetap. Tanpa perubahan peningkatan ini, maka frekuensi muatan generator akan naik, sedangkan frekuensi sistem tidak boleh berubah. Oleh karena itu ketika pengaturan uap masuk ditingkatkan maka secara otomatis arus eksitasi akan meningkat

\subsection{Simulasi Generator Simulasi Generator dengan Simulink Matlab}

Simulasi yang dilakukan pada generator menggunakan Matlab Simulink dimana generator yang dimodelkan adalah generator sinkron 3 fasa 3,125

MVA.Spesifikasi generator pada simulasi berbeda dengan spesifikasi generator di PT Sumber Segara Primadaya, hal ini dikarenakan keterbatasan data parameter generator, hydraulic turbine governor dan sistem eksitasi di lapangan. Namun pada prinsipnya, cara kerja generator pada simulasi ini sama dengan generator di PT Sumber Segara Primadaya. 


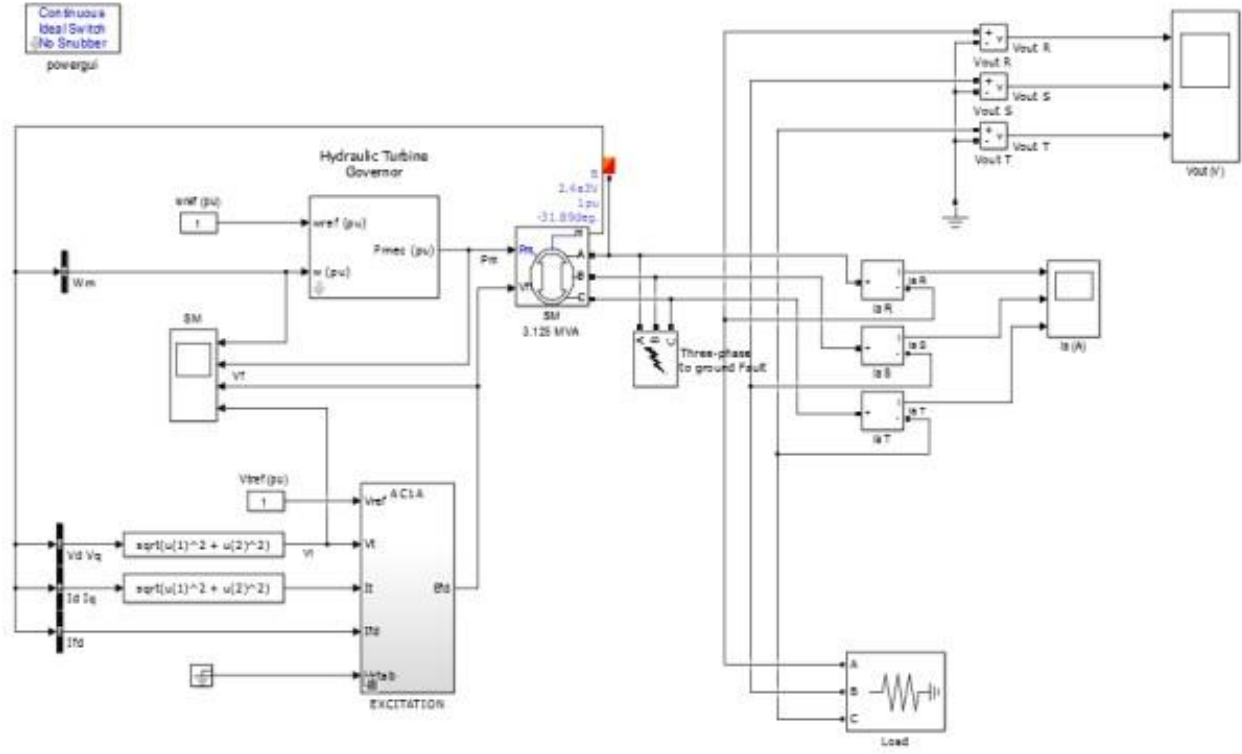

Gambar 3.11 Pemodelan Generator Sinkron

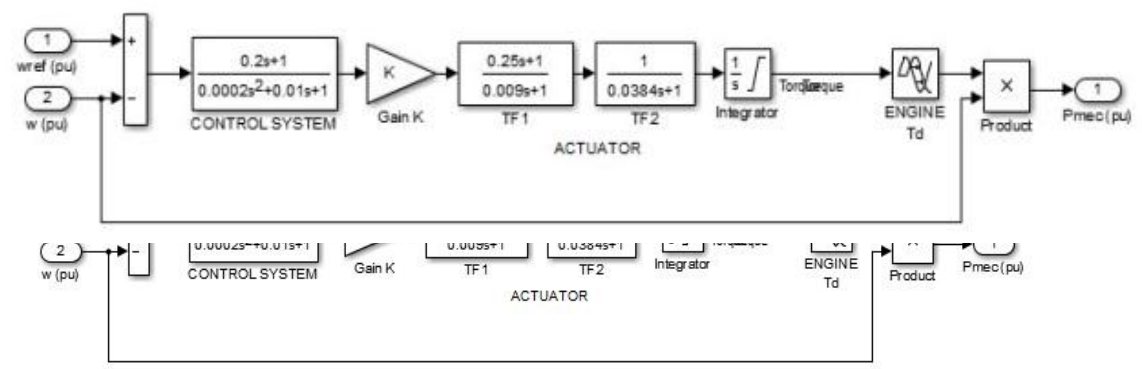

Gambar 3.12 Model Operasi Hydraulic Turbine Governor 


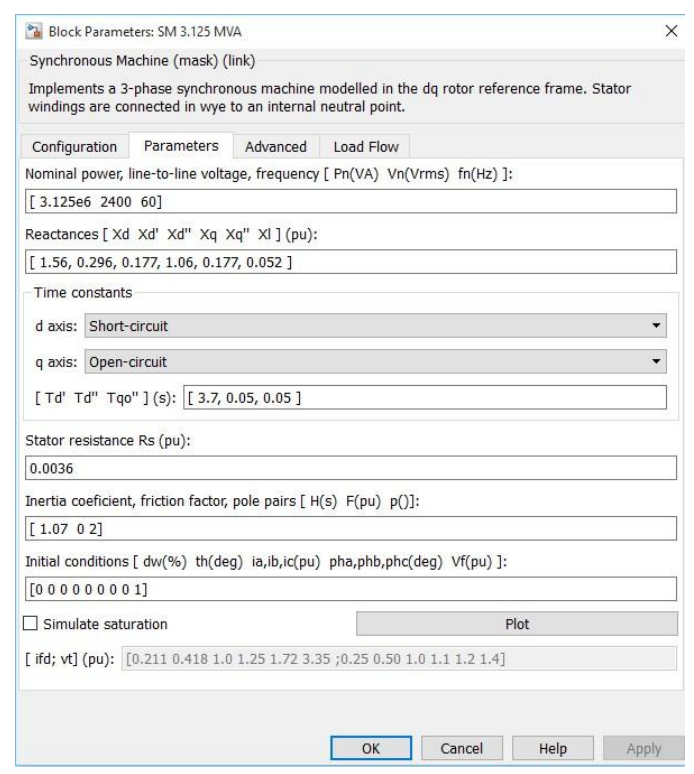

Gambar 3.13 Parameter Simulasi Generator Sinkron

\subsection{Pengujian Variasi Beban 3 Fasa}

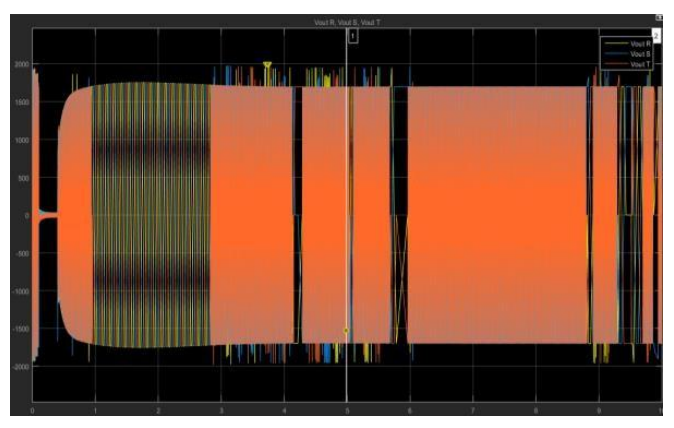

Gambar 3.14 Tegangan Output Generator Beban 1MW 1/2

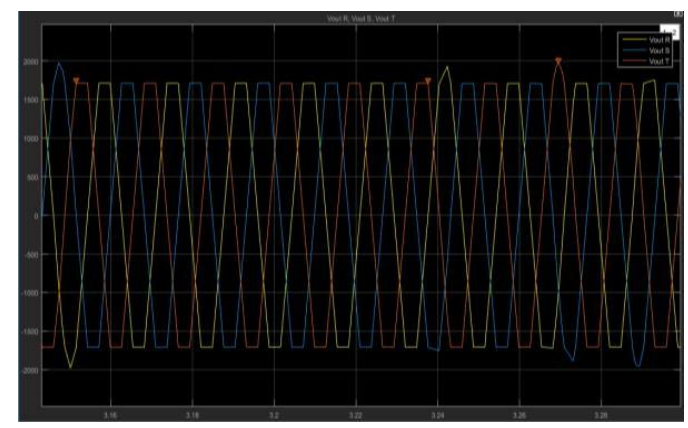

Gambar 3.15 Tegangan Output Generator pada Beban 1 MW 2/2 


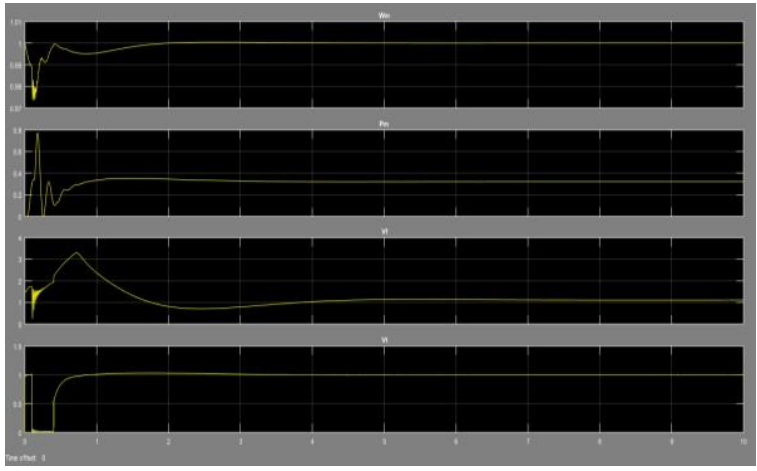

Gambar 3.16 Input Generator (HTG \& Eksitasi) pada Beban 1 MW

Dari pengujian tersebut, dapat diketahui bahwa besarnya tegangan Output generator stabil karena telah diatur oleh AVR. Sedangkan besarnya arus berbanding lurus dengan besarnya beban generator. Kemudian beban generator juga turut berpengaruh terhadap input generator. Semakin besar beban yang diterima generator, maka semakin panjang juga durasi yang diperlukan generator untuk mencapai kondisi stabil.

\subsection{Pegujian Beban 3 Fasa (Daya Aktif \& Reaktif)}

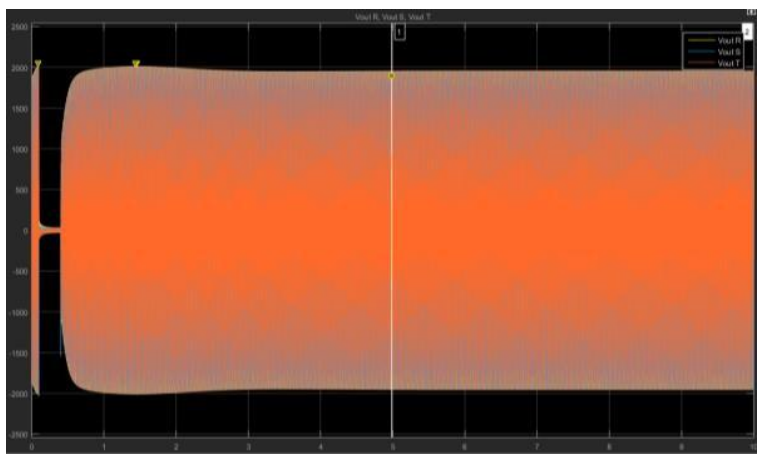

Gambar 3.17 Tegangan Output Generator pada Pegujian Beban 3 Fasa (Daya Aktif \& Reaktif) 1/2

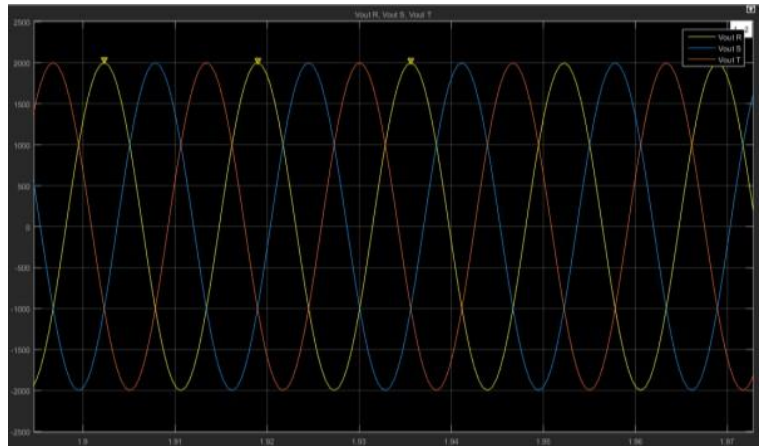

Gambar 3.18 Tegangan Output Generator pada Pegujian Beban 3 Fasa (Daya Aktif \& Reaktif) 2/2 


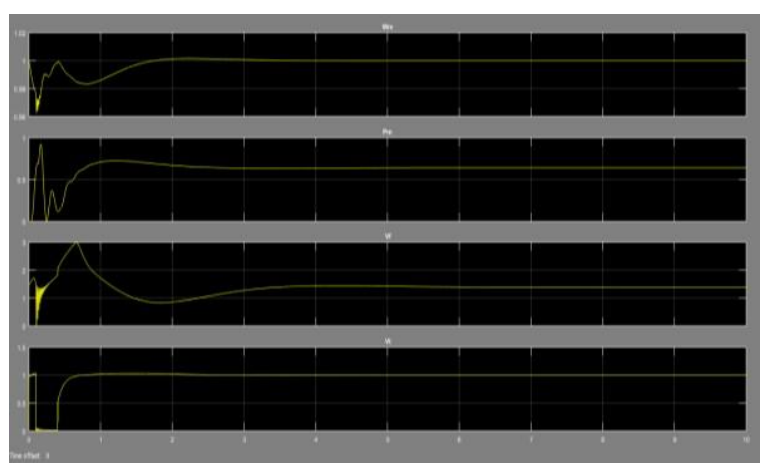

Gambar 3.19 Input Generator (HTG \& Eksitasi) pada Pengujian Beban 3 Fasa ( Daya Aktif \& Reaktif)

Pengujian beban 3 fasa sebesar 2 MW dan 0,25 MVAR ini menunjukan bahwa adanya daya reaktif pada beban generator menyebabkan kualitas tegangan dan arus keluaran generator lebih baik dibandingkan dengan generator tanpa beban reaktif. Hal ini dapat terlihat dari lebih stabilnya frekuensi pada sinyal keluaran generator.

\subsection{Pengujian Beban Lebih}

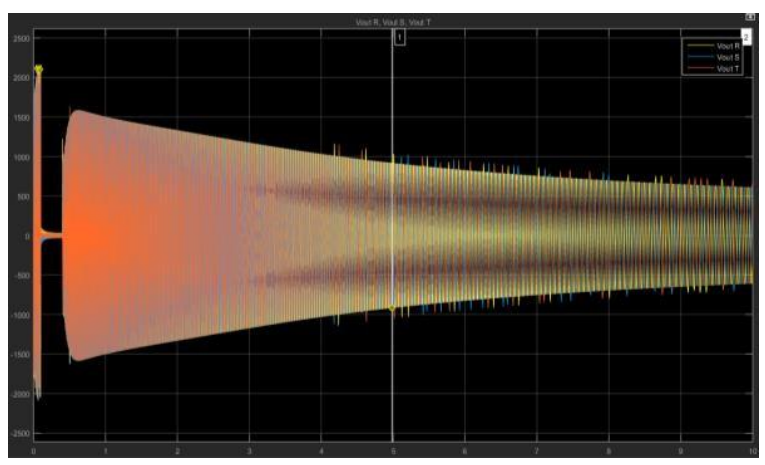

Gambar 3.20 Tegangan Output Generator pada Pegujian Beban Lebih

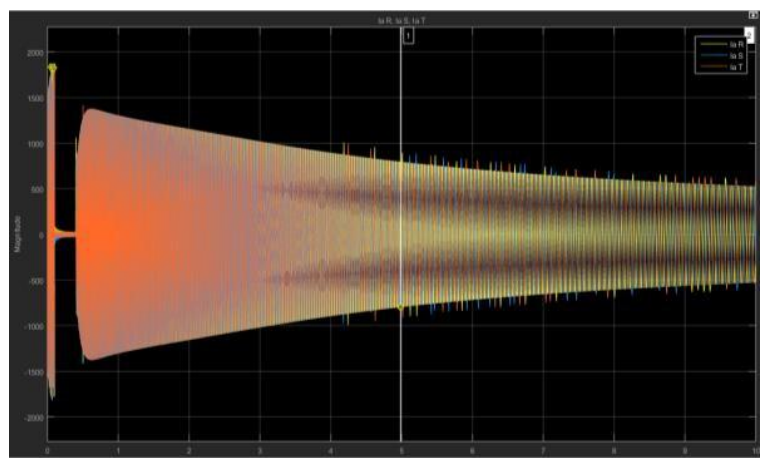

Gambar 3.21 Arus Beban pada Pegujian Beban Lebih 


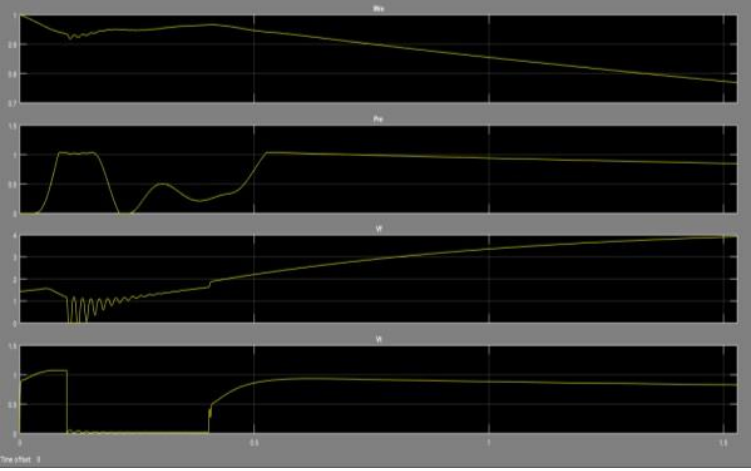

Gambar 3.22 Input Generator (HTG \& Eksitasi) pada Pegujian Beban Lebih

Dari pengujian ini, dapat diketahui bahwa generator akan mengalami penurunan performa ketika diberi beban melebihi kapasitasnya. Kinerja generator yang awalnya berada pada kondisi normal akan mengalami penurunan seiring dengan bertambahnya waktu pembebanan.

\subsection{Pengujian Beban Tidak Seimbang}

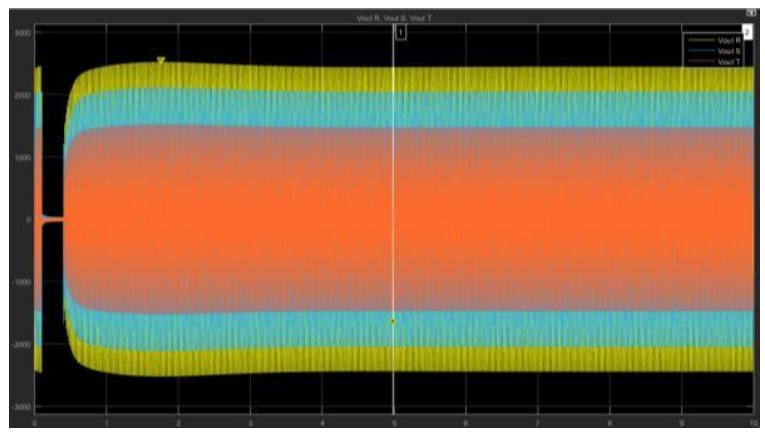

Gambar 3.23 Tegangan Output Generator pada Pengujian Beban Tidak Seimbang 1/2

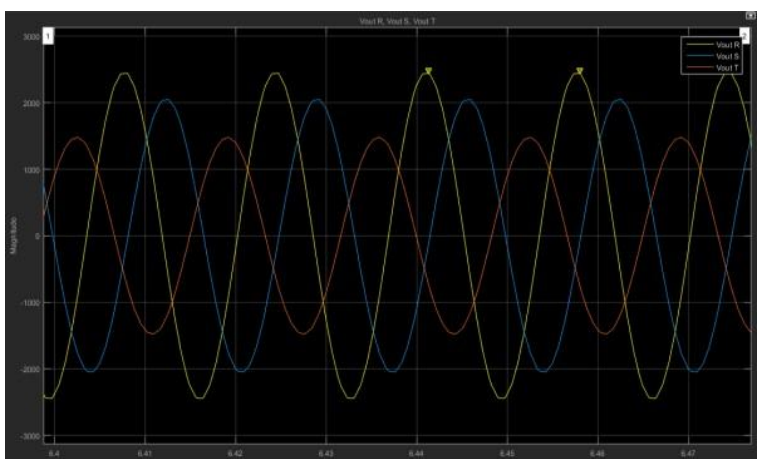

Gambar 3.24 Tegangan Output Generator pada Pegujian Beban Tidak Seimbang 2/2

Halaman Web JRRE : http://jurnalnasional.ump.ac.id/index.php/JRRE 


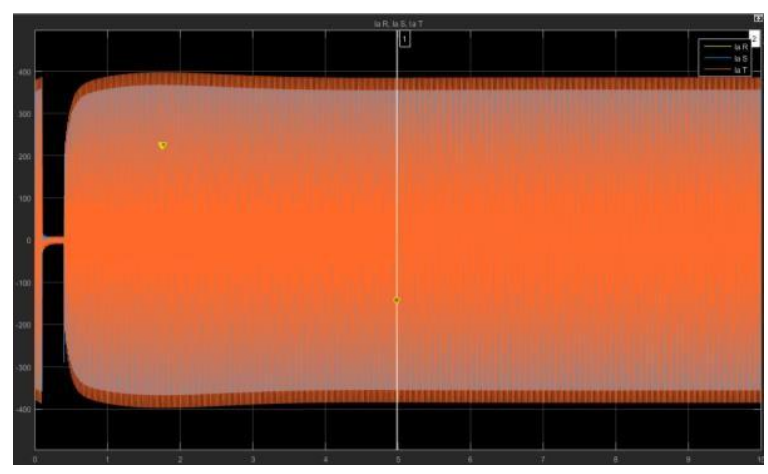

Gambar 3.25 Arus Beban pada Pegujian Beban Tidak Seimbang 1/2

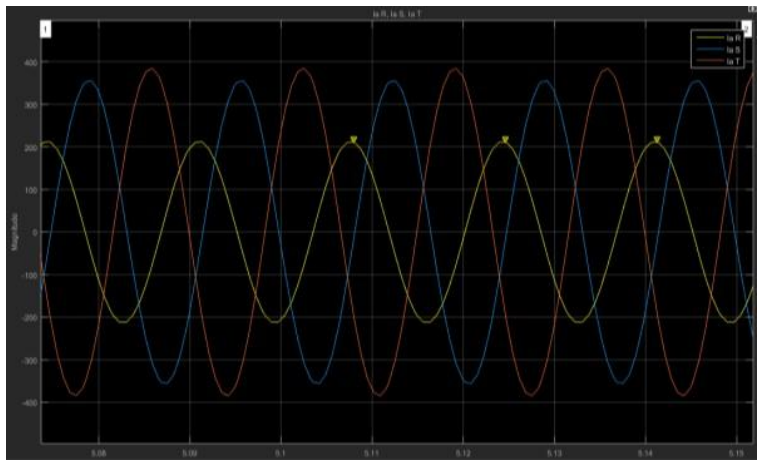

Gambar 3.26 Arus Beban pada Pegujian Beban Tidak Seimbang 2/2

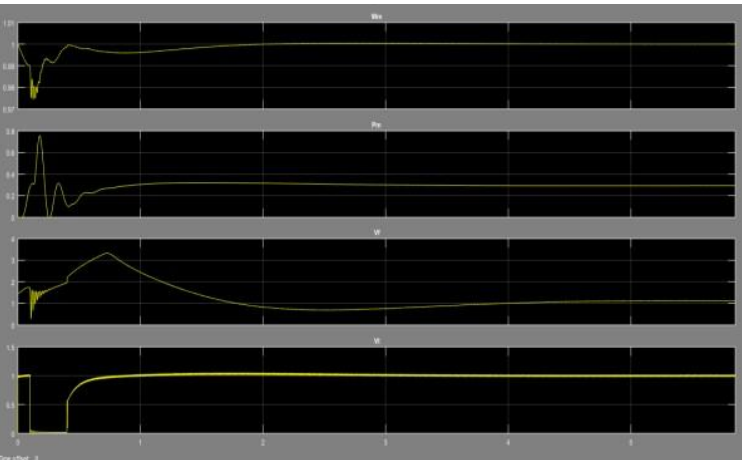

Gambar 3.27 Input Generator (HTG \& Eksitasi) pada Pegujian Beban Tidak Seimbang

Pengujian beban tidak seimbang menunjukkan bahwa tegangan Output generator tidak bisa stabil mengikuti rated tegangannya. Semakin tinggi beban suatu fasa, maka semakin rendah tegangan keluarannya. Namun semakin tinggi beban suatu fasa, semakin tinggi pula arus bebannya. Beban tidak seimbang ini merupakan gangguan yang dapat memperpendek umur stator karena tidak terjaganya kestabilan arus pada stator, gangguan ini juga tidak baik untuk keamanan kumparan generator, maka dari itu beban setiap fasa suatu generator3 fasa haruslah seimbang.

Halaman Web JRRE : http://jurnalnasional.ump.ac.id/index.php/JRRE 


\subsection{Pengujian Gangguan pada Exciter}

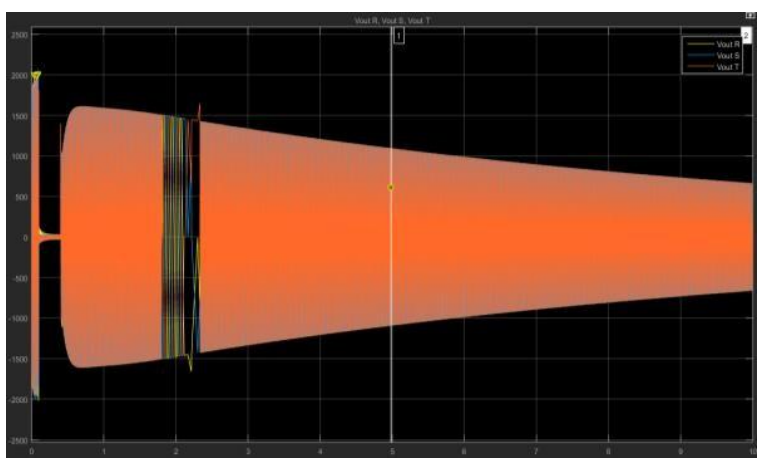

Gambar 3.28. Tegangan Output Generator pada Pengujian Gangguan pada Excitter

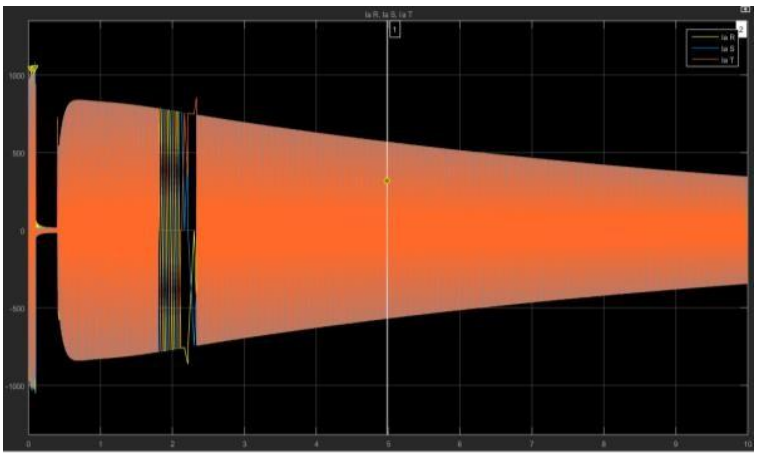

Gambar 3.29 Arus Beban pada Pegujian Gangguan pada Exciter

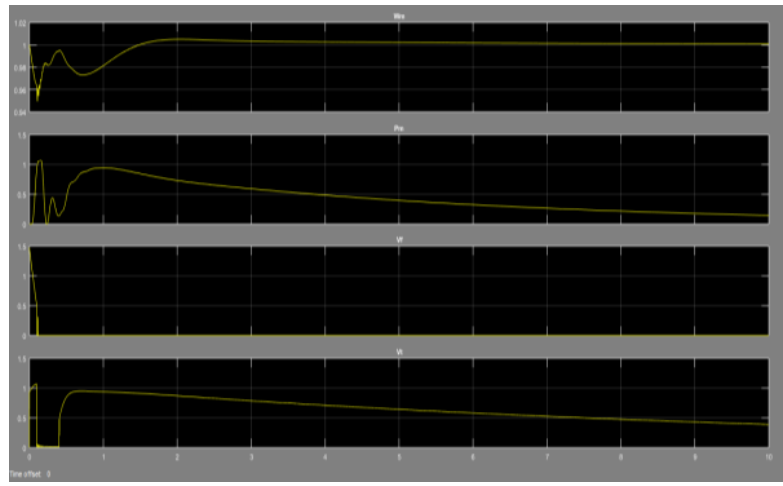

Gambar 3.30 Input Generator (HTG \& Eksitasi) pada Pegujian Gangguan pada Exciter

Gangguan yang terjadi pada exciter menyebabkan sistem eksitasi pada generator melemah menuju nilai 0, sehingga keluaran generator pun akan melemah. Generator tidak bisa bekerja dengan baik menghasilkan energi karena medan magnet yang dibuat oleh eksitasi tidak bekerja dengan baik walaupun prime movernya bekerja secara normal.

Halaman Web JRRE : http://jurnalnasional.ump.ac.id/index.php/JRRE 


\subsection{Pengujian Persgeseran Sudut Fasa}

Tabel 4.1 Ringkasan Sudut Fasa

\begin{tabular}{|c|c|c|c|c|}
\hline Sudut Fasa & $3 \theta=1 \mathrm{MW}$ & $3 \theta=2 \mathrm{MW}$ & $3 \theta=3 \mathrm{MW}$ & $\Sigma 1 \theta=3 \mathrm{MW}$ \\
\hline$\theta \mathrm{R}_{\mathrm{rms}}$ & $126,070^{\mathrm{O}}$ & $125,385^{\mathrm{O}}$ & $125,885^{\mathrm{O}}$ & $154,393^{\circ}$ \\
\hline$\theta \mathrm{S}_{\mathrm{rms}}$ & $127,380^{\mathrm{O}}$ & $127,440^{\mathrm{O}}$ & $127,805^{\circ}$ & $130,036^{\mathrm{O}}$ \\
\hline$\theta \mathrm{T}_{\mathrm{rms}}$ & $129,041^{\mathrm{O}}$ & $129,146^{\mathrm{O}}$ & $127,984^{\mathrm{O}}$ & $139,258^{\mathrm{O}}$ \\
\hline
\end{tabular}

Sistem 3 fasa menyebabkan terjadinya pembagian sudut fasa menjadi 3 bagian. Sistem 3 fasa yang benar-benar seimbang akan memiliki besar sudut senilai 120o untuk setiap fasanya. Namun mengingat rugirugi yang tidak mungkin dihilangkan dari suatu sistem serta beban yang sangat fluktuatif, menjadi mustahil suatu sistem memiliki pembagian beban yang sangat seimbang. Namun dengan sistem manajemen yang baik dapat diperoleh pembagian beban setiap fasa yang mendekati seimbang.

Dalam pengujian pergeseran sudut fasa ini, diketahui bahwa sudut fasa untuk setiap varian beban 3 fasa yang diuji memiliki nilai sekitar 120o pada setiap fasanya. Namun hal tersebut tidak nampak untuk 3 buah beban 1 fasa tidak seimbang di setiap fasa yang memiliki jumlah senilai 3 MW. Pada beban tidak seimbang ini, dapat diketahui bahwa sudut fasanya berada pada range nilai 130,036o sampai dengan 154,3930. Hal ini tentu tidak baik karena menyebabkan sistem menjadi tidak stabil sehingga dapat menurunkan kinerja generator. 


\section{KESIMPULAN}

Setelah melakukan penelitian dan menganalisa data-data yang diperoleh selama melakukan penelitian di PT Sumber Segara Primadaya, maka penulis dapat menyimpulkan beberapa hal yaitu:

a. Beban harian generator unit 1 \& 2 PT Sumber Segara Primadaya bersifat sangat fluktuatif. Umumnya beban tinggi terjadi pada pukul 19.00-21.00 WIB.

b. Perubahan beban generator unit 1 \& 2 PT Sumber Segara Primadaya yang terjadi tidak terlalu mempengaruhi tegangan outputnya. Hal ini dikarenakan peran AVR (Automatic Voltage Regulator) sebagai stabilitator tegangan output.

c. Perubahan beban generator unit 1 \& 2 PT Sumber Segara Primadaya berbanding lurus dengan perubahan arus beban yang terjadi. Hal ini disebabkan oleh besarnya resistansi dan tegangan yang tidak berubah saat terjadi perubahan beban.

d. Perubahan beban generator unit $1 \& 2$ PT Sumber Segara Primadaya turut mempengaruhi perubahan arus medan/eksitasi pada exciter. Pada saat terjadi perubahan beban, set point governor juga mengalami perubahan, pengaturan uap masuk inilah yang membuat arus eksitasi otomatis berubah.

e. Perubahan beban generator unit 1 \& 2 PT Sumber Segara Primadaya mempengaruhi durasi yang dibutuhkan HTG (Hydraulic Turbine Governor) dan exciter untuk mencapai kondisi stabil. Semakin besar beban yang diterima generator, maka akan semakin panjang durasi yang dibutuhkan.

f. Perubahan beban generator unit 1 \& 2 PT Sumber Segara Primadaya juga mempengaruhi cos phi generator. Sedangkan cos phi generator berpengaruh langsung terhadap efisiensi generator. Efisiensi generator unit $1 \& 2$ berada pada rentang 97,12 \% sampai dengan 98,73\%. Angka ini cukup baik mengingat rugi yang dihasilkan maksimal hanya sebesar 2,88\%.

g. Meninjau simulasi generator sinkron 3 fasa dengan Simulink Matlab, gangguan-gangguan yang terjadi pada input maupun output generator hendaknya jangan sampai terjadi, karena sangat mempengaruhi kestabilan kinerja generator bahkan dapat merusak generator.

h. Untuk menjaga generator tetap dalam keadaan stabil, baiknya perubahan beban diatur supaya perubahannya tidak terlalu signifikan. Batas maksimum beban generator senantiasa juga perlu diperhatikan dalam rangka pemeliharaan generator.

\section{DAFTAR PUSTAKA}

[1] Bandri, Sepannur. 2013. Analisa Pengaruh Perubahan Beban terhadap Karakteristik Generator Sinkron (Aplikasi PLTG Pauh Limo Padang). Padang: Institut Teknologi Padang.

[2] Higuchi, Tsuyoshi. 2014. Design Analysis of a Novel Synchronous Generator for Wind Power Generation. Nagasaki: Nagasaki University.

[3] Kristof, Vladimir. 2017. Loss of Excitation of Synchronous Generator. Kosice: Slovenska Technicka Univerzita.

[4] Selwa, Fetissi, Labed Djamel. 2014. Transient Stability Analysis of Synchronous Generator in Electrical Network. Constantine: Mentouri University Route d'Ain El Bey. 